\title{
Morphometric Relief Aspects Identification of Khabour River Basin
}

\section{Jinan Rahman Ibrahim}

Department of Geography, Faculty of Arts, Soran University, Soran, Kurdistan Region, Iraq jinan.ibrahim@soran.edu.iq

\section{ARTICLE INFO}

\section{Article History:}

Received: $1 / 4 / 2021$

Accepted:30/5/2021

Published: Spring 2021

\section{Keywords:}

Relief characteristics, River basin, River erosion, sediments.

Doi:

10.25212/Ifu.qzj.6.2.37

\begin{abstract}
Relief Aspects provides data regarding erosion properties of the river basin, such as the morphological properties of the relief, overall slop, and erosion severity. The Khabour River Basin has severe slopes, resulting in high runoff and soil erosion. This creates large latent energy to move water and sediment downward per unit of length. Besides, the ruggedness number of the study area basin is (7.23). The high value indicates that the area is characterized by rugged relief soil erosion and structural complexity. Furthermore, the dissection index (Dis) of the study area which was 0.50 , indicates that the basin is still in the youth stage and its reliefs are in constant development instead of morphmetrical Hezel and the sub-Khabour. Hezel River basin has relatively higher values than Al Khabour River main and subbasin. For example, the slop of the Hezel River basin is (34.73), while the main Khabour Basin (23.7), compared to al- Khabwr sub-Basin (22.60) and the river canal slope (22.1) , while the slope of the sub-Khabour River canal (14.4). The Hezel Basin also has a significant increase in the relief number, relative relief ratio, and ruggedness number. The study area basin is characterized by the modern geomorphology, the activity of water erosion factors, the high proportions of both stripping and transferred materials and basin runoff speed which resulted in a decrease in the percentage of filtered water to the subsurface layers due to the complex nature of the mountain basin, the slop intensity and surface ruggedness.
\end{abstract}




\section{INTRODUCTION}

Morphometric analysis is the measurement of the geometric shape of any natural shape, plant, animal, or relief aspect [1]. The morphometric study in recent decades, since the 1940s in particular, has been significantly involved in applied geomorphology studies according to the purpose and objective of the study, such as the analysis of sediment quantities, flood hazards, relief severity, age or degradation stage of the given area for three main reasons: identifying the river drainage basin as a basic geomorphic unit in studies of the evolution of the Earth shape, the urgent need for quantitative data to accompany processes in practical response models, and finally the philosophical and methodological transformation of geomorphology from self-paced and forward-looking science based on observations to objective and inductive science based on measurements [2]. One aspect of the morphometric study of aquatic basins is the analysis of the landscape, as it highlights the importance of the river basin relief study since it is a reflection of the increased effectiveness and activity of erosion processes and their impact on the formation of the Earth surface within the basin boundaries. This reverse their geomorphological history. Through this, the erosional stage can be determined, how it affects, and affected by the geological and structural differences in the activity of erosion factors [3]. We conclude [4] that there is a relationship between the slope of the basin and erosion rates, so the less the basin relief, the lesser sediments in the drainage basin, as they affect the movement of water and sediments. Moreover, relief aspects are also important and necessary to understand the spatial arrangement of the relief in the river basin or any area. This facilitates better investment and more rational use of certain regions. The study aims at understanding the extent to which these characteristics affect the speed of erosion and the development of the basin, and the corrasion stage of the river, because erosion and morphological characteristics of the terrain in any river basin are a reflection of the geomorphological phase of the basin. Studies of the study area were limited to [6],[5] and [7] of Mount Becheir in the north of Dohuk, which is passed by water division line of al Khabwr sub-Basin at the southern end of the study area and studying [8] climate changes and its impact on the water sources of the Khabour River in the Kurdistan region of Iraq, which in general did not mention the 
relief aspects and their characteristics of the Khabour basin from the source to its meeting with the Tigris River.

\section{Study area:}

The study area, Khabour Basin River, is located between longitudes $43^{\circ} 30^{\circ}$ and $42^{\circ}$ $20^{\prime}$ East, and latitude $36^{\circ} 55^{\prime}$ and $37^{\circ} 50^{\prime} \mathrm{N}$, Northwest of Dohuk Governorate, Kurdistan Region of Iraq. It is the first tributaries to the Tigris River at the Iraqi-TurkishSyrian border triangle. The area is about $\left(6024.42 \mathrm{~km}^{2}\right)$. The upper basin is located in the province of eastern Anatolia, Turkey which is a river crossing the Iraqi-Turkish borders including $(2592.15 \mathrm{~km} 2)$ in Iraq, and (3432.27 km2) in Turkey. It was mentioned by [8] that the average annual flow of Khabour is $\left(68 \mathrm{~m}^{3} / \mathrm{sec}\right)$ with a high seasonal influx in May and low seasonal flow from July to December. 30\% of the basin is covered by wetland forests while $23 \%$ of the basin has agricultural activity. No dams or regulatory bodies were built on the Khabour River. The basin consists of two main tributes, the River Hezel (Hazel Soo), with an area of (2183.42 km2), and (36.24\%) of the total area of the main basin, including $(277.08 \mathrm{~km} 2)$ in Iraq. It flows from Sirnak in Turkey to run south-west [9] forming the Iraqi-Turkish border. The river meets the second tributary Al Khabour (9.22) km west of Zakho city in Dohuk governorate. SubKhabour River is located at $42^{\circ} 25^{\prime}-43^{\circ} 5^{`} \mathrm{~N}, 37^{\circ} 10^{`}-37^{\circ} 50^{`} \mathrm{~N}$ ). Its first sources consist of a group of tributaries and waterways sloping from the Polkar Mountains, Southeast Al-Hakkar in Turkish Uludere region [10]. Al Khabour sub-basin area is about (3508.27 km2), and it constitutes (58.23\%) of the total basin area, of which (2198.68 km2) in Iraq (Table 1). It flows north-east-southwest passing through Zakho after the two tributaries meet, the river remains known as the Khabour River until it meets the Tigris River, at the Iraqi-Turkish-Syrian border triangle, north of Fish Khabour village at longitude $42^{\circ} 20^{`} \mathrm{E}$, and a latitude of $37^{\circ} 06^{`}$ North, traveling 20 $\mathrm{km}$ along the Iraqi-Turkish border (Figure 1 ).

As a result of the lack of climate data on Turkey's Hezel basin, data from the Weather Service and Dohuk Agriculture Directorate (temperature, humidity, and rain) for 1980-2016 were collected. The region has been shown to have seasonal precipitation 


\section{QALAAI ZANISTSCIENTIFIC JOURNAL}

A Scientific Quarterly Refereed Journal Issued by Lebanese French University - Erbil, Kurdistan, Iraq

Vol. (6), No (2), Spring 2021

ISSN 2518-6566 (Online) - ISSN 2518-6558 (Print)

that is concentrated in the cold season while summer is a hot and dry season, making the region both within the Mediterranean climate and its effects (Table 2).

Table 1. Some of the spatial properties of the Khabour River basin and its sub tributes

\begin{tabular}{|l|c|c|c|c|c|}
\hline Basins & Area $\mathrm{Km}^{2}$ & $\begin{array}{l}\text { Total Area } \\
\text { Percentage \% }\end{array}$ & $\begin{array}{l}\text { Basin Area in } \\
\text { Iraq Km² }\end{array}$ & $\begin{array}{l}\text { Basin Area } \\
\text { Percentage \% }\end{array}$ & $\begin{array}{l}\text { Basin Area in } \\
\text { Turkey Km² }\end{array}$ \\
\hline Hazel & 2183.42 & 36.24 & 277.08 & 12.69 & 1906.34 \\
\hline Sub Khabour & 3508.27 & 58.23 & 2198.68 & 62.67 & 1309.594 \\
\hline Main Basin & 6024.42 & ---- & 2592.15 & 43.03 & 3432.27 \\
\hline
\end{tabular}

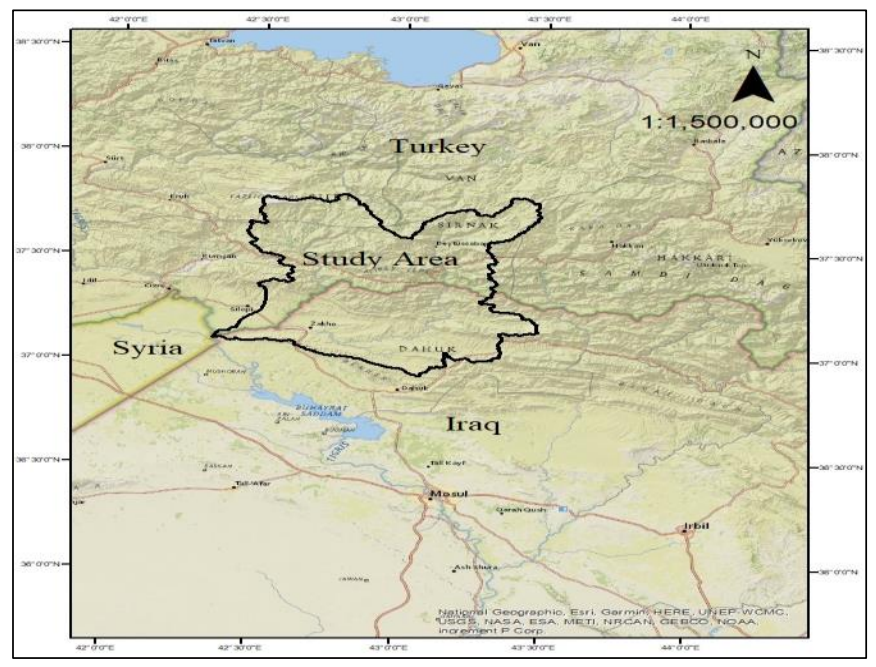

Figure 1. Study area location

Source: Researcher's work using GIS

Table 2. Rainfall ( $\mathrm{mm}$ ) and seasonal temperature rates of the climate stations in the study area of the period (1980-2016)

\begin{tabular}{|c|c|c|c|c|c|c|c|c|}
\hline $\begin{array}{c}\text { Season } \\
\text { station }\end{array}$ & \multicolumn{2}{|c|}{ winter } & \multicolumn{2}{c|}{ spring } & \multicolumn{2}{c|}{ Summer } & \multicolumn{2}{c|}{ Fall } \\
\hline & rain & $\begin{array}{c}\text { temp } \\
\text { eratu } \\
\text { re }\end{array}$ & rain & $\begin{array}{c}\text { tem } \\
\text { pera } \\
\text { ture }\end{array}$ & rain & $\begin{array}{c}\text { temperatur } \\
\text { e }\end{array}$ & rain & $\begin{array}{c}\text { temp } \\
\text { eratu } \\
\text { re }\end{array}$ \\
\hline
\end{tabular}




\section{QALAAI ZANISTSCIENTIFIC JOURNAL}

A Scientific Quarterly Refereed Journal Issued by Lebanese French University - Erbil, Kurdistan, Iraq

Vol. (6), No (2), Spring 2021

ISSN 2518-6566 (Online) - ISSN 2518-6558 (Print)

\begin{tabular}{|c|c|c|c|c|c|c|c|c|}
\hline Zakho & $\begin{array}{c}319 . \\
4\end{array}$ & 7 & 198.6 & 15 & 105.4 & 26 & 2.9 & 16 \\
\hline Dohuk & $\begin{array}{c}285 . \\
9\end{array}$ & 8 & 172.4 & 20 & 88.8 & 27 & 0.8 & 17 \\
\hline Amede & 380 & 10 & 292 & 16 & 159.3 & 24 & 4.1 & 14 \\
\hline Simil & $\begin{array}{c}248 . \\
7\end{array}$ & 5 & 152.3 & 15 & 80.4 & 22 & 0.3 & 15 \\
\hline $\begin{array}{c}\text { Total } \\
\text { Rate }\end{array}$ & $\begin{array}{c}123 \\
4\end{array}$ & 7.5 & 815.3 & 16.5 & 433.9 & 24.7 & 8.1 & 15.5 \\
\hline
\end{tabular}

Source: Researcher's work depending on

1. Iraqi Kurdistan Region, Ministry of Transport and Communications, Department of Weather, Dohuk Station, unpublished data for the period (1980-2016).

2. Iraqi Kurdistan Region, Ministry of Agriculture and Irrigation, Dohuk Agriculture Directorate, Agricultural Climate Department, unpublished data for the period (1980-2016).

The geological formations in the study area vary from the Paleozoic to the Mesozoic and the Cenozoic. These formations extend to Turkey's southeast Anatolia, where the River Hezel basin is located [7\&11]. The largest formations of the study basin and the most age-old (Urduveshi) is Khabour Quartzite Formation which is characterized by the high proportion of sand and parasite materials while its sedimentary environment is a shallow marine environment, covered by a layer of red volcanic eruptions, called the formation of red Bersebeki and the formation of volcanic Halki (Devonite era)[11\& 12]. It is also characterized by application, fossils, and sedimentary structures, for sedimentation in various environments, rivers, deltoid, slopes, and flat basins [13]. The formation of the (Triassic era), limestone, Marley limestone, shale stone, and the oolitic limestone is weak in resistance to dissociation, erosion by high permeability and solubility $[12,14,15$ \&16].

As for Cenozoic formation, they consist of Marl, clay Marl, Dolomite Marl, claylimestone, red claystone, Alluvial and sandy stone, mostly converted to Dolomite evaporations (gypsum, anhydrates and salt rocks), crystalline chalky limestone and knots of lime. It is more vulnerable to various erosional and weathering factors, so it 


\section{QALAAI ZANISTSCIENTIFIC JOURNAL \\ A Scientific Quarterly Refereed Journal Issued by Lebanese French University - Erbil, Kurdistan, Iraq \\ Vol. (6), No (2), Spring 2021 \\ ISSN 2518-6566 (Online) - ISSN 2518-6558 (Print)}

has many cracks and cavities and is a good reservoir of groundwater $[14,16,17$, and 18].

The formations of the Pliocene era are the thick basin layers clay, Celtic, sandy, thickfilled blocks of mammals, and coarse river materials. These materials have resulted from the erosion of high mountain areas in basins below these mountains. The fourth era increased water erosion [12], with which river sedimentation, erosion, and the deposition of erosion products in different forms and sizes, down valleys, around the waterways, in the vines and the lowlands (Figure 2).

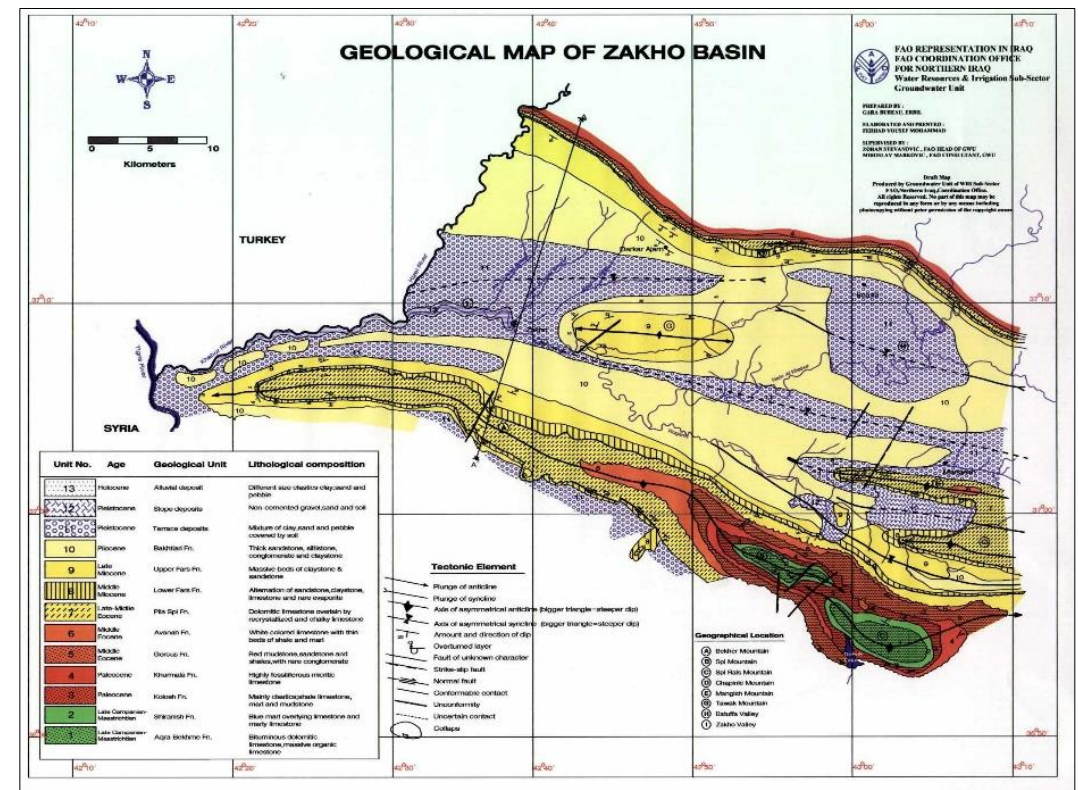

Figure 2. Khabour Basin geology in Iraq.

\section{Methodology:}

GIS (ArcGIS 10.4.1) and remote sensing techniques have been used as a tool for morphometric analysis, climate data collection and use of the Digital Elevation Model (DEM) to build a morphometric and hydrological database of the main basin of $\mathrm{Al}$ Khabour using the latest modern radar techniques, spatial analysis, and relief assessment through relevant morphometric indicators, analysis of the structure of the water drainage system and knowledge of the topography development of the study area. Also, topographic and other natural properties are linked to the 1008 


\section{QALAAI ZANISTSCIENTIFIC JOURNAL \\ A Scientific Quarterly Refereed Journal Issued by Lebanese French University - Erbil, Kurdistan, Iraq \\ Vol. (6), No (2), Spring 2021 \\ ISSN 2518-6566 (Online) - ISSN 2518-6558 (Print)}

hydrological characteristics and behavior of the aquarium. The study also adopted the topographic maps of the Zakho area (NJ 38-9) and (NJ38-13), issued by the Military Survey Directorate - Baghdad, on a scale of 1: 250,000 for the year 2000. Also, the laws of geomorphologists pioneers such as Stirler, Milton, Miller, Schum and others have been implemented (Table 3 ).

Table 3. The relief characteristics, laws, and sources of the study area

\begin{tabular}{|c|c|c|}
\hline Indicators & Equation & Source \\
\hline The top of the basin/ M & GIS Software Analysis & ------ \\
\hline The bottom of the basin/ M & GIS Software Analysis & ------ \\
\hline Absolute Relife (AR) & GIS Software Analysis & ------ \\
\hline Basin relief $(R)$ & $\mathrm{R}=\mathrm{H}-\mathrm{h}$ & Schumm (1956) \\
\hline Relief ratio $\mathrm{Rh}$ & $\mathrm{Rh}=\mathrm{R} / \mathrm{Lb}$ & Schumm (1956) \\
\hline (Rhp) Relative Relief Ratio & $\mathrm{Rhp}=\mathrm{R} / \mathrm{P} * 100$ & Melton (1958) \\
\hline (Rn) Ruggedness number & $\mathrm{Rn}=\mathrm{R}^{*} \mathrm{Dd} / 1000$ & Schumm (1956) \\
\hline $\mathrm{MRn}$ & $\mathrm{MRn}=\mathrm{R} / \mathrm{A} 0.5$ & Melton (1965) \\
\hline (Gn) Geometry Number & $(G n)=R n / R h$ & Abo reya (2007) \\
\hline (Dis) Dissection index & Dis= $\mathrm{H}-\mathrm{h} / \mathrm{H}$ & Sing \& Dubey (1994) \\
\hline (Sb)Basin Slope & $\mathrm{Sb}=\mathrm{R} / \mathrm{Lb}$ & Miller (1953) \\
\hline (Cg) Channel Gradient & $\mathrm{Cg}=\mathrm{R} /\{(\pi / 2) * \mathrm{Lb}\}$ & Singh et al. (2014) \\
\hline (Rg) Gradient ratio & $\mathrm{Rg}=\mathrm{R} / \mathrm{Lr}$ & Sreedevi et al. (2009) \\
\hline Total Contour Length (CtI) Kms & GIS Software Analysis & ------ \\
\hline$(\mathrm{L} 1+\mathrm{L} 2) \mathrm{Km}$ & GIS Software Analysis & Strahler (1952) \\
\hline Contour Interval (Cin) & GIS Software Analysis & ------- \\
\hline mean slope of overall basin (Өs) & $\theta s=(\mathrm{Ctl} * \mathrm{Cin}) / \mathrm{A}$ & Chorley (1972) \\
\hline Average Slope (S) & $\mathrm{S}=\left(\mathrm{Z}^{*}(\mathrm{Ctl} / \mathrm{H}) /\left(10^{*} \mathrm{~A}\right)\right.$ & Wenthworth (1930) \\
\hline$(\mathrm{Swc})$ & $\mathrm{Swc}=\mathrm{A} /\{(\mathrm{L} 1+\mathrm{L} 2) / 2\}$ & Strahler (1952) \\
\hline
\end{tabular}

\section{Results and discussions:}

Morphometric studies of river basins are important for studying river behavior, slope, river sedimentation, river change, riversides' erosion, etc. To address erosion and related problems through statistical analysis of the studied river basin data, the study found the following findings, which are shown in Table (4):

Relief ratio $(\mathrm{Rh})$ \& Basin relief $(\mathrm{R})$ 
Basin relief $(R)$ represents the difference in vertical distance between the top height and the lowest height in the basin in meters [19]. The main basin relief is (2999 $\mathrm{m}$ ), $(2943 \mathrm{~m})$ for the Al-Khabour sub-basin, and $(8222 \mathrm{~m})$ for the Hezel basin. The basin relief has an important role to play in developing the features of the land, the drainage system, the surface and groundwater flow, the permeability as well as the corrosive properties of the terrain.

The rate at which the basin is to the maximum length in meters is called Relief ratio (Rh) [19]. The main basin relief is about $(2999 \mathrm{~m}),(2943 \mathrm{~m})$ of Al Khabour sub-basin, and $(8222 \mathrm{~m})$ for the Hezel basin. The basin relief has an important role to play in developing land features, the drainage system, the surface and groundwater flow, the permeability characteristic, and also the erosional properties of the landforms.

The basin relief ratio to the maximum basin length in meters is called the Relief ratio (Rh) [19]. It is an indication of the severity of the erosion that slopes the basin and thus it is a measure of the overall slope of the drainage basin [20]. According to [21] there is a close correlation between the loose sediments in the area unit and the rate of the relief ratio. It affects understanding the topology of the basin and contributes to the formation of different forms of geomorphology, as well as estimating the size and quality of the transported sediment and its impact can be extended far beyond it. Furthermore, it contributes to the rapid arrival of water output, reflected in the increased effectiveness of river erosion and associated large-scale sediment transport. In this study, the RH reached for the main Khabour river basin (29.14). Lower values indicate moderate slope, low reliefs resulting from underground resistance to erosion [22]. The relief ratio increases as the basin area decreases [23]. Due to the small size of the Hezel river sub-basin, the length of the basin is short from the main basin and the Khabour sub-basin with a difference of approximately $177 \mathrm{~m}$ and $121 \mathrm{~m}$, respectively, of the two basins, which are not striking and important, the $\mathrm{RH}$ value of the Hezel River basin is the highest (34.0). The relief ratio in khabour river basin is (21.5). This has made the Hezel River Basin one of the most important study areas in terms of the activity of eroding and retreating towards the sources, its surface runoff is more effective and strong in the transmission of sediment production (Figure 3). 


\section{QALAAI ZANISTSCIENTIFIC JOURNAL}

A Scientific Quarterly Refereed Journal Issued by Lebanese French University - Erbil, Kurdistan, Iraq

Vol. (6), No (2), Spring 2021

ISSN 2518-6566 (Online) - ISSN 2518-6558 (Print)

Khabour River basin

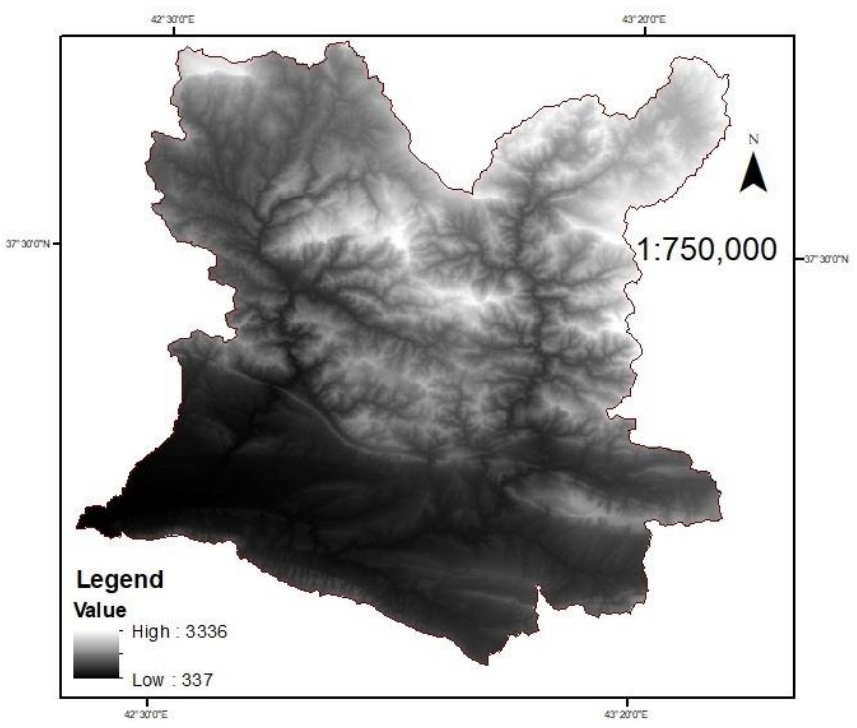

Hezel River Sub-basin

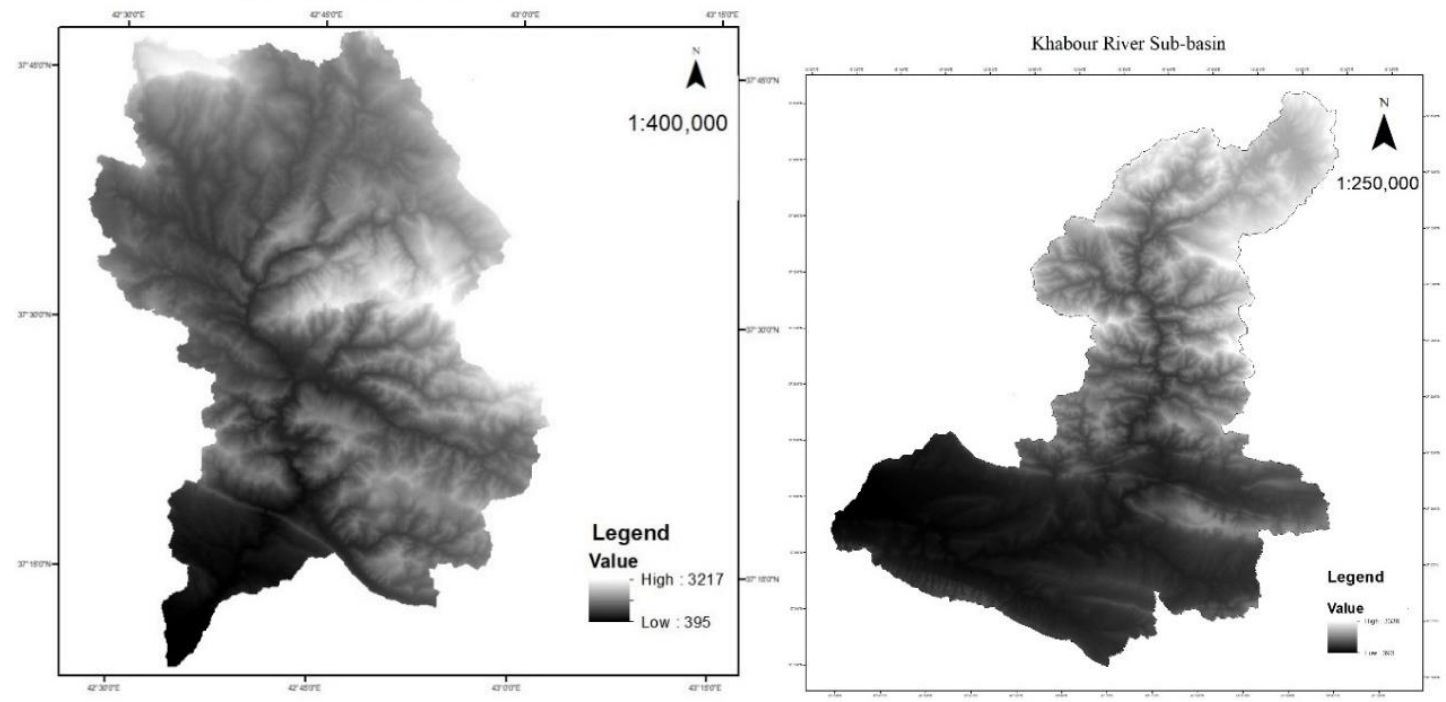

Figure (3) shows the digital model of the main river basin of Khabour and its two sub-basins 
It is one technology that can effectively introduce the relief characteristics with consideration of sea level [24] and due to the relation of its values with rock resistance, erosion factor activity, and basin size. Some [25] have classified relief ratio into three categories: Low $0-100 \mathrm{~m}$, moderate $100-300 \mathrm{~m}$, and high if more than $300 \mathrm{~m}$. The higher the value, the more rock resistance increases with the weaker erosion factors and smaller basin indicating that the basin is still in the early stages of the river erosion cycle. Conversely, low values are associated with the activity of the sculpture process, regression toward sources, undermining water-splitting areas and thus the possibility of river capture indicates the stage of youth. The relative relief numbers of the study area basin are generally very high, as they are (585.6), for the main Khabour basin, (696.1), and (1015.1) for Khabour sub-basins and Hezel basin respectively. Depending on [25] the basin is still at the beginning of its erosion cycle due to its mountainous nature and resistant to its rocks for erosion factors. The RHP is the highest in the Hezel sub-basin due to its very complex reliefs compared to the small basin area and Khabour sub-basin

\section{Melton ruggedness number (MRn) and Ruggedness number ( $R n)$}

The ruggedness number is closely related to the reliefs, water dynamics, and water drainage basin development. Numbers are very high when variables, the relief, and the drainage intensity are large. This happens when slopes are not only too steep but also long [26]. The ruggedness number is therefore reduced at the beginning of the basin's life cycle and then begins to increase to its maximum level at the beginning of the maturity phase and then begins to decrease again at the end of the life cycle. This means that the ruggedness number increases with the increased basin relief along with the increase in the length of the river waterways at the expense of the basin area and thus the increase in water-degradation and sediment transfers [27]. The study area was characterized by mean ruggedness number reaching 3.5 for the study area, while 3.4 and 3.2 for Khabour and Hezel sub-basins respectively. Thus, all these numbers indicate that the main basin (with its sub-basins) is still at the beginning of its erosive cycle, and there is ample time to complete its cycle and the short length of its waterways concerning the basin area. The ruggedness number of the study area and its sub-basins correspond to melton ruggedness number (MRn) which is an indication of the spatial representation of the relief in the basin [28] that reached in 
the study area (80.7) and (49.4) and (60.25) for Khabour and Hezel sub-basins respectively. This refers that the clinical sediments are dominant in the basin according to [29] classification due to the basin's slope and complex relief.

Geometry Number (Gn)

The geometric number measures the relationship between the ruggedness number and relief ratio and thus the composite correlation between the drainage density, the basin relief, and its surface slope degree [30]. The geometric number for the study area basin is (0.12), (0.16) for Khabour sub-basin, and (0.09) for Hezel sub-basin. This indicates the relative modernity of the basins and their reduced drainage density.

Dissection index (Dis)

It is an indicator of dissection index or vertical erosion and the development stages of the relief or surface topography in any given physiographic area or river basin [31]. [32] indicated that (Dis) numbers are basically a percentage between 0 and 1 (i.e. $0 \%$ $-100 \%$ ) divided into three groups of (Dis) numbers $1 \%-10 \%, 2 \%-30 \%$ and $30 \%$ or more. Although Khabour main and sub-basins (Dis) numbers are very close, they are very high, reaching (0.90) for the main Khabour basin and $(0.88)$ for its sub-basins. These very high numbers indicate that the basin's relief is still evolving due to the relief intensity resulting from the mountainous nature of the area, and thus its vertical erosion activity.

Basin Slope (Sb)

Based on [26] the basin slope (Sb) is a measure of the ratio of surface water filtration to the subsurface layers of the region, and a general indicator of the intensity of the basin slope and the intensity of erosion processes operating on the surface of the basin. The more the slope of the basin is, the more erosion and a lower percentage of filtered water and vice versa. Accordingly, the basin slope was determined in several ways. The slope of the main basin according to [33] is (29.1), the Khabour subBasin (21.5), and the (34.0) of Hazel River Basin. As for the Average Slope (S), a method [34] was used. The slope number was (0.34) for the studied basin and 
Khabour sub-basin, but this rate rises in the Hazel basin to (0.42). While the mean slope of the overall basin (Os) presented by [35] for the main basin, (613.5), (602.4), and (734.2) for Khabour and Hezel sub-basins respectively.

Depending on ASTER-DEM, the studied basin was divided into 7 slope classes and the areas occupied by each class were determined. It was found that the steepest areas occupy the largest area, with a percentage of (50.9\%) for the study area basin, $(47.8 \%)$ and (60.1\%) for Khabour and Hezel sub-basins, see Table (5) and Map (4).

Channel Gradient $(\mathrm{Cg})$ and Gradient ratio $(\mathrm{Rg})$

[36] Considers that Channel Gradient ( $\mathrm{Cg}$ ) slope helps determine the drainage increase of the downstream, or its ability to move slope sediments. The higher its value, the more channel can transmit sediments. The result was for the study area basin (18.6), (13.7), and (21.7) for Khabour and Hezel sub-basins. The Gradient ratio (Rg) [37], which allows the assessment of surface runoff volume [38], was (22.2) for the main Al-Khabour basin, (14.4) and (25.7) for Khabour and Hezel sub-basins respectively.

Since it is impacted by the slope of the basin and the properties of the rock its high and low values indicate the nature of the area if it was mountainous or plain [39]. In general, the main basin is characterized by mountainous nature, mainstream slope intensity, and high flow velocity. Also, Hezel river channel is steeper due to its more complex mountainous nature, its small area, and the shorter basin length, which is reflected in the severity of its slope. As for Khabour sub-basin, it is despite its high number but its large area and the length of its basin made its course less steep. Accordingly, the Hezel Basin is the most used basin for its drainage and sediment transport capacity.

\section{Contour Lines}

As a result of the surface complexity and intensity of elevations, the study area was divided into 15 areas, with a contour separation of (200) $\mathrm{m}$. See Figure (5) and extract the contour lines. Table (6) shows the average Slope Width of Contour (Swc) to 


\section{QALAAI ZANISTSCIENTIFIC JOURNAL \\ A Scientific Quarterly Refereed Journal Issued by Lebanese French University - Erbil, Kurdistan, Iraq \\ Vol. (6), No (2), Spring 2021 \\ ISSN 2518-6566 (Online) - ISSN 2518-6558 (Print)}

analyze basin relief by extracting the sum of the lengths of two adjacent contour lines $(\mathrm{L} 1+\mathrm{L} 2)[1]$. The Swc of the main Al-Khabour basin was (2.4), (3.02) and (1.58) for Khabour and Hezel sub-basins respectively.

Curve and heptometric integration

The hyposometric curve $(\mathrm{Hc})$ is related to the size of the surface mass and the amount of erosion that occurred in a basin, against the remaining mass [40]. The hematometric integration ( $\mathrm{Hsi}$ ) is the area below the curve, and it is also an indication of the erosion cycle, the total time needed to reduce the area of the Earth to the base level where the lowest level is as a percentage [41]. It is the remains of the current size compared to the original size of the basin [42]. Pike and Wilson's (1971) method was used in [43] to determine the heptometric integration of the study area, which was (0.61) for the study area basin, (0.63) for Khabour sub-basin and (0.64) for Hezel sub-basin. This indicates that the main basin and its sub-basin are in the youth and balance stage, where the water basin is subject to severe erosion and $[41,44]$. Figure (6).

Table (4) Results of the measured indicators of Khabour main and sub-basins

\begin{tabular}{|c|c|c|c|}
\hline Basin indicators & $\begin{array}{c}\text { Main } \\
\text { Khabour }\end{array}$ & $\begin{array}{c}\text { Sub } \\
\text { Khabour }\end{array}$ & Hezel \\
\hline Area in Km ${ }^{2}$ & 6026.8 & 3550.3 & 2193.8 \\
\hline perimeter Km & 512.1 & 422.8 & 278 \\
\hline Basin length / km (Lb) & 102.9 & 136.95 & 82.9 \\
\hline Length of main river km (L) & 135.02 & 204.09 & 101.0 \\
\hline Total water group lengths / km (Lu) & 7020.8 & 4066.4 & 2456.3 \\
\hline Drainage density km / km ${ }^{2}(\mathrm{Dd})$ & 1.2 & 1.1 & 1.1 \\
\hline Highest Height (H) & 3336 & 3336 & 3217 \\
\hline Lowest Height (H) & 337 & 393 & 395 \\
\hline Basin relief (R) & 2999 & 2943 & 2822 \\
\hline
\end{tabular}




\section{QALAAI ZANISTSCIENTIFIC JOURNAL}

A Scientific Quarterly Refereed Journal Issued by Lebanese French University - Erbil, Kurdistan, Iraq

Vol. (6), No (2), Spring 2021

ISSN 2518-6566 (Online) - ISSN 2518-6558 (Print)

\begin{tabular}{|c|c|c|c|}
\hline Relief ratio (Rh) & 29.14 & 21.5 & 34.0 \\
\hline Relative Relief ratio (Rhp) & 585.6 & 696.1 & 1015.1 \\
\hline Ruggedness number (Rn) & 3.5 & 3.4 & 3.2 \\
\hline $\begin{array}{l}\text { Melton ruggedness number } \\
\text { (MRn) }\end{array}$ & 80.7 & 49.4 & 60.25 \\
\hline Geometry Number(Gn) & 0.12 & 0.16 & 0.09 \\
\hline Dissection index (Dis) & 0.90 & 0.88 & 0.88 \\
\hline Basin Slope (Sb) & 29.1 & 21.5 & 34.04 \\
\hline Channel Gradient (Cg) & 18.6 & 13.7 & 21.7 \\
\hline Gradient ratio (Rg) & 22.2 & 14.4 & 25.4 \\
\hline Total lengths of contour lines & 18488.6 & 11140.3 & 8053.54 \\
\hline $\begin{array}{l}\text { The length of two contiguous contour lines } \\
\qquad \mathrm{L} 1+\mathrm{L} 2\end{array}$ & 5050.810469 & 2348.2 & 2779.61 \\
\hline Contour interval Cin & 200 & 200 & 200 \\
\hline Mean slope of overall basin (Өs) & 643.6 & 627.6 & 734.2 \\
\hline Slope rate & 0.36 & 0.36 & 0.42 \\
\hline Average Slope Width of Contour (Swc) & 0.6 & 3.03 & 1.58 \\
\hline Integral Hypsometry & 0.61 & 0.63 & 0.64 \\
\hline
\end{tabular}

Table 5. Slope classes and mean slope of the study area and sub-basins

\begin{tabular}{|c|c|c|c|c|c|c|c|c|}
\hline Basin & classes & $5-0$ & $12-5$ & $18-12$ & $24-18$ & $32-24$ & $44-32$ & $100-44$ \\
\hline \multirow{2}{*}{ Main basin } & Area km² & 523.0 & 928.4 & 797.7 & 709.0 & 784.9 & 912.9 & 1370.9 \\
\cline { 2 - 8 } & $\%$ & 8.7 & 15.4 & 13.2 & 11.8 & 13.0 & 15.1 & 22.7 \\
\hline $\begin{array}{c}\text { Basin slope } \\
\text { average }\end{array}$ & \multicolumn{70}{|c|}{32.0} \\
\hline
\end{tabular}




\section{QALAAI ZANISTSCIENTIFIC JOURNAL}

A Scientific Quarterly Refereed Journal Issued by Lebanese French University - Erbil, Kurdistan, Iraq

Vol. (6), No (2), Spring 2021

ISSN 2518-6566 (Online) - ISSN 2518-6558 (Print)

\begin{tabular}{|c|c|c|c|c|c|c|c|c|}
\hline \multirow{2}{*}{$\begin{array}{c}\text { Khabour sub- } \\
\text { basin }\end{array}$} & Area $\mathrm{km}^{2}$ & 312.36 & 674.32 & 489.14 & 379.16 & 398.96 & 491.43 & 804.93 \\
\hline & $\%$ & 8.8 & 19.0 & 13.8 & 10.7 & 11.2 & 13.8 & 22.7 \\
\hline $\begin{array}{c}\text { Basin slope } \\
\text { average }\end{array}$ & \multicolumn{8}{|c|}{31.1} \\
\hline \multirow{2}{*}{$\begin{array}{l}\text { Hezel sub- } \\
\text { basin }\end{array}$} & Area $\mathrm{km}^{2}$ & 69.6 & 204.7 & 284.7 & 314.8 & 371.7 & 405.2 & 541.6 \\
\hline & $\%$ & 3.2 & 9.3 & 13.0 & 14.4 & 17.0 & 18.5 & 24.7 \\
\hline $\begin{array}{c}\text { Basin slope } \\
\text { average }\end{array}$ & \multicolumn{8}{|c|}{35.5} \\
\hline
\end{tabular}
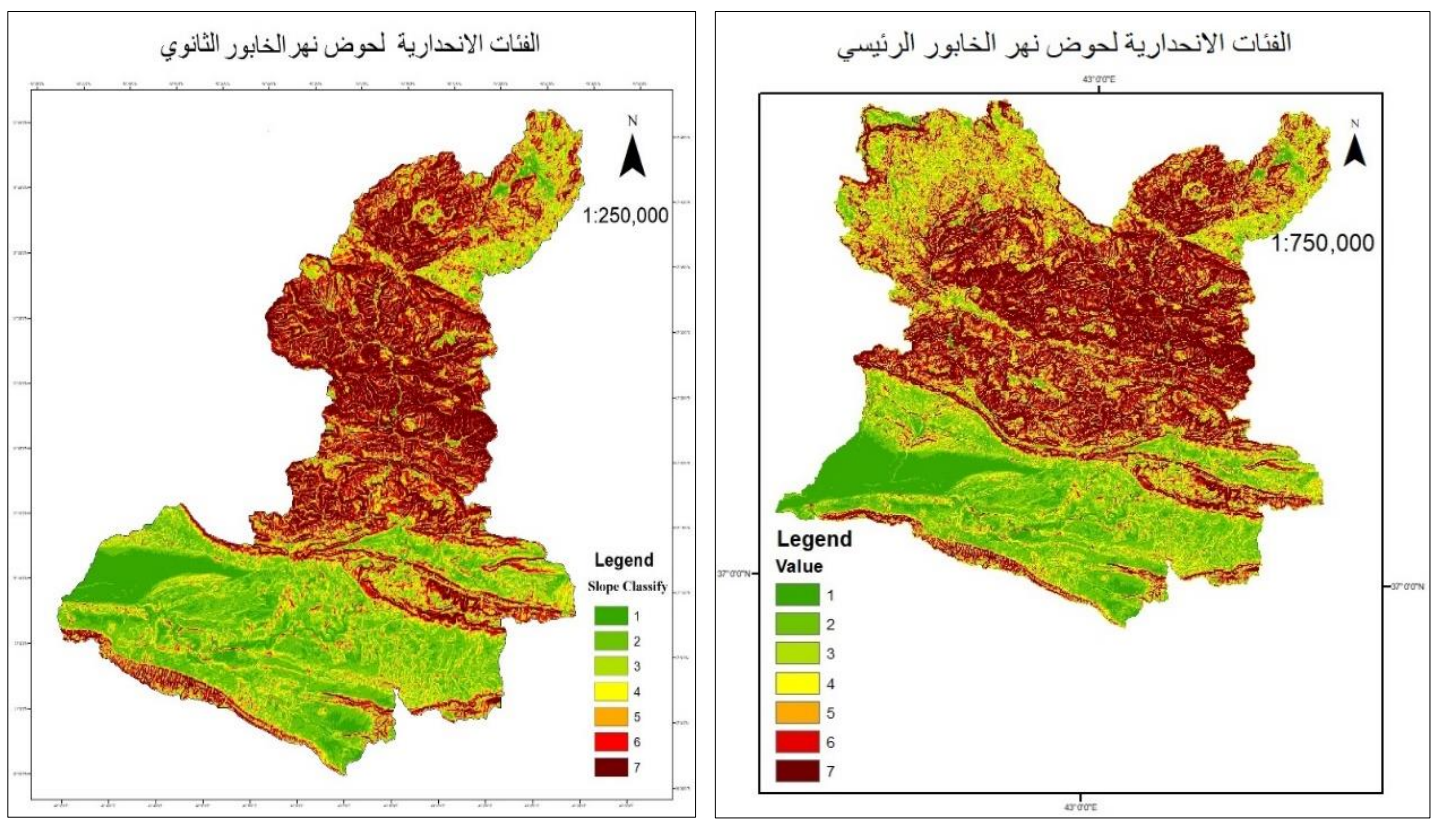


\section{QALAAI ZANISTSCIENTIFIC JOURNAL}

A Scientific Quarterly Refereed Journal Issued by Lebanese French University - Erbil, Kurdistan, Iraq

Vol. (6), No (2), Spring 2021

ISSN 2518-6566 (Online) - ISSN 2518-6558 (Print)

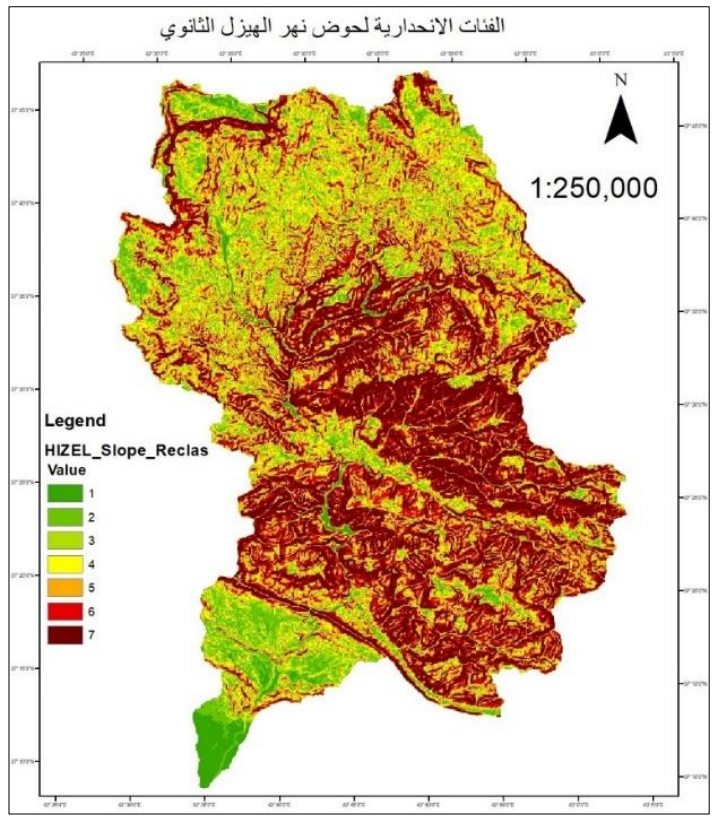

Figure 4. Khabour main and sub-basins slope classes

Table (6) study area basin and the sub-basin contour lines lengths and areas between them

\begin{tabular}{|c|c|c|c|c|c|c|}
\hline \multicolumn{2}{|l|}{ Hezel sub-basin } & \multicolumn{2}{l|}{ Khabour sub-basin } & \multicolumn{2}{l|}{ Khabour main basin } \\
\hline $\begin{array}{c}\text { Lentour } \\
\text { Lenth km }\end{array}$ & $\begin{array}{c}\text { Con. Area } \\
\mathrm{km}^{2}\end{array}$ & $\begin{array}{c}\text { Contour } \\
\text { Length km }\end{array}$ & $\begin{array}{c}\text { Con. } \\
\text { Area km² }\end{array}$ & $\begin{array}{c}\text { Min.- } \\
\text { Max. }\end{array}$ & $\begin{array}{c}\text { Contour } \\
\text { Length km }\end{array}$ & $\begin{array}{c}\text { Con. } \\
\text { Area } \\
\mathrm{km}^{2}\end{array}$ \\
\hline $337-500$ & 213.1 & 285.7 & $\begin{array}{c}(393- \\
500) \\
121.3\end{array}$ & 97.8 & $\begin{array}{c}(395-500) \\
62.4\end{array}$ & 36.3 \\
\hline $500-700$ & 756.8 & 629.7 & 516.2 & 472.1 & 171.3 & 102.9 \\
\hline $700-900$ & 1296.2 & 699.4 & 900.5 & 561.1 & 345.0 & 109.4 \\
\hline $900-1100$ & 1782.3 & 624.7 & 1054.6 & 437.7 & 679.6 & 173.7 \\
\hline $1100-1300$ & 2340.9 & 638.6 & 1128.4 & 298.8 & 1182.6 & 329.9 \\
\hline $1300-1500$ & 2633.1 & 654.0 & 1135.1 & 257.9 & 1457.5 & 386.2 \\
\hline $1500-1700$ & 2540.3 & 627.2 & 1206.2 & 256.1 & 1322.1 & 363.2 \\
\hline $1700-1900$ & 2061.9 & 488.4 & 1094.6 & 230.3 & 963.5 & 254.4 \\
\hline $1900-2100$ & 1480.5 & 321.1 & 866.3 & 172.4 & 619.8 & 147.8 \\
\hline $2100-2300$ & 1234.7 & 302.1 & 805.9 & 200.2 & 437.2 & 101.5 \\
\hline $2300-2500$ & 1106.3 & 270.6 & 774.9 & 189.7 & 353.6 & 80.1 \\
\hline
\end{tabular}




\section{QALAAI ZANISTSCIENTIFIC JOURNAL}

A Scientific Quarterly Refereed Journal Issued by Lebanese French University - Erbil, Kurdistan, Iraq

Vol. (6), No (2), Spring 2021

ISSN 2518-6566 (Online) - ISSN 2518-6558 (Print)

\begin{tabular}{|c|c|c|c|c|c|c|}
\hline $2500-2700$ & 913.4 & 233.0 & 666.4 & 172.7 & 257.5 & 59.4 \\
\hline $2700-2900$ & 640.6 & 179.5 & 517.3 & 140.9 & 139.0 & 37.8 \\
\hline $2900-3100$ & 317.5 & 59.5 & 282.0 & 51.5 & 46.5 & 5.0 \\
\hline $3100-3336$ & 78.0 & 12.7 & 70.4 & 11.2 & - & 4.3 \\
& & & & & $(31003217) 15$ & \\
& & & & & & \\
\hline & 19395.5 & 6026.3 & 11140.3 & 3550.3 & 8053.5 & 2192.0 \\
\hline
\end{tabular}

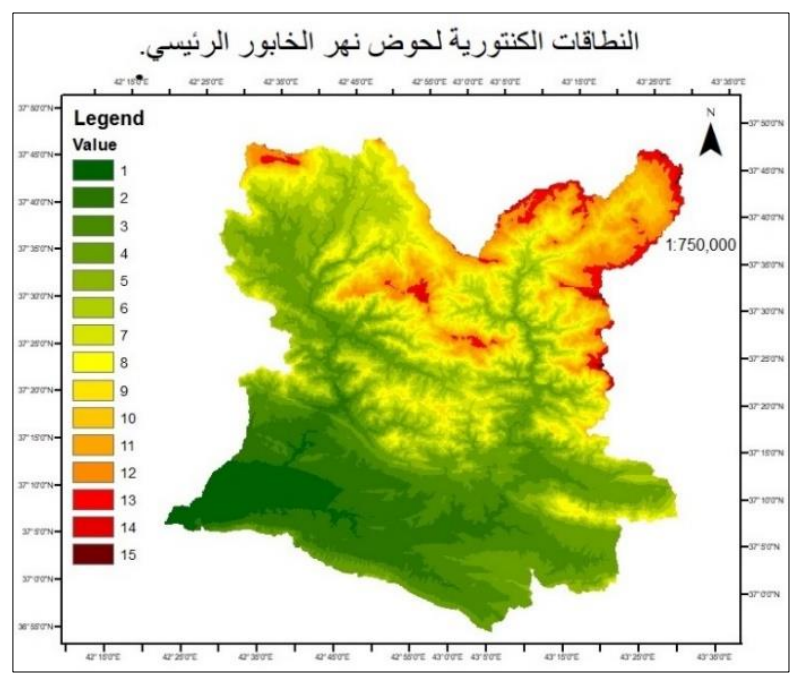




\section{QALAAI ZANISTSCIENTIFIC JOURNAL}

A Scientific Quarterly Refereed Journal Issued by Lebanese French University - Erbil, Kurdistan, Iraq

Vol. (6), No (2), Spring 2021

ISSN 2518-6566 (Online) - ISSN 2518-6558 (Print)

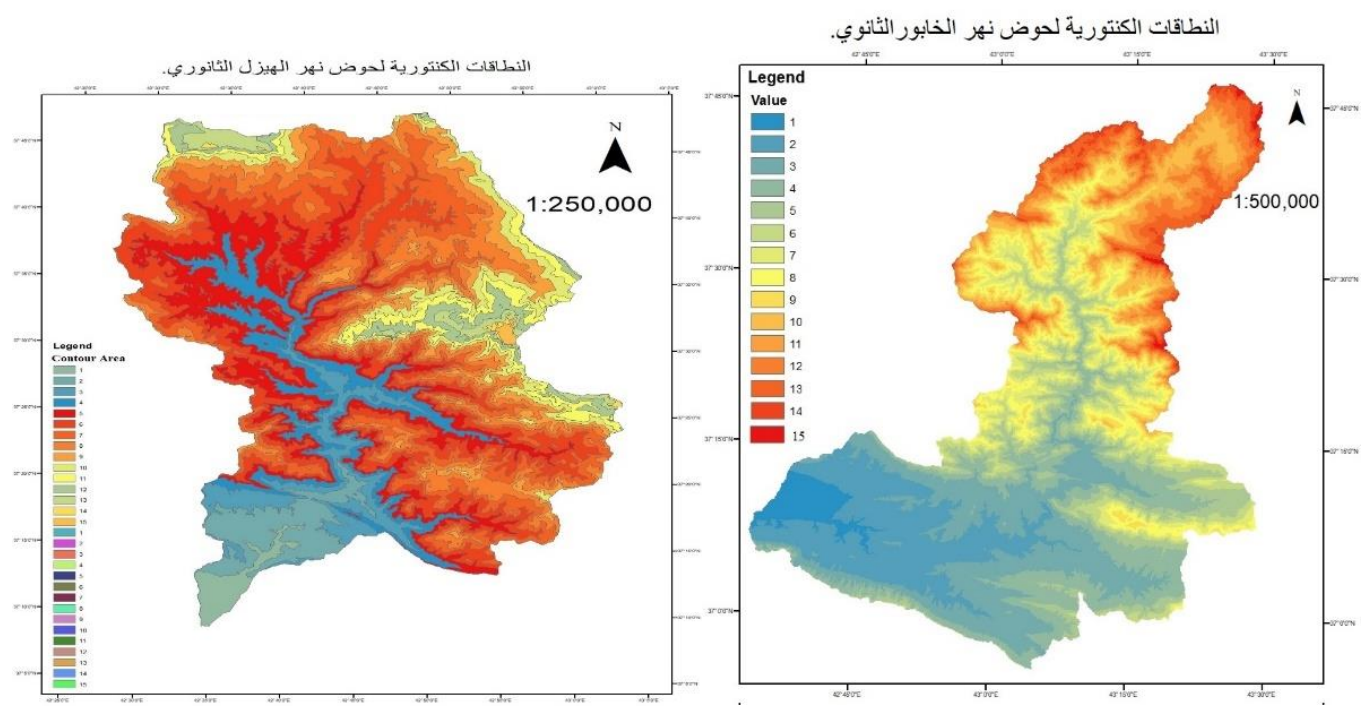

Figure (5) contour areas of Khabour River main and sub-basins

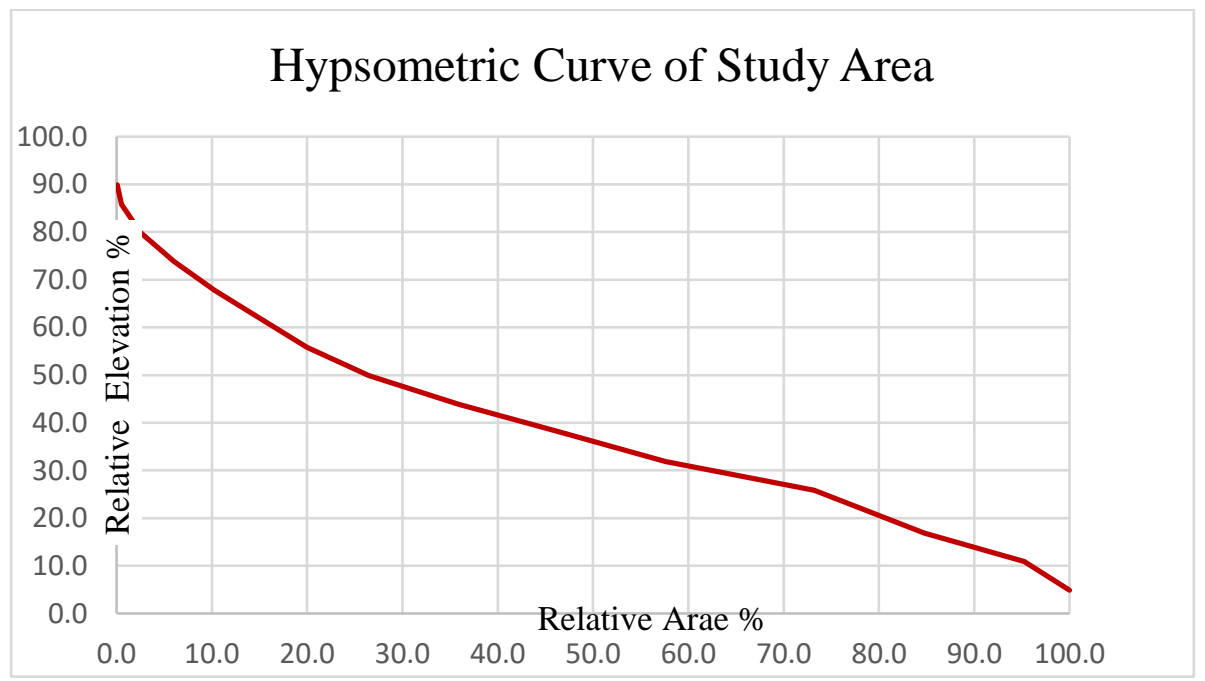




\section{QALAAI ZANISTSCIENTIFIC JOURNAL}

A Scientific Quarterly Refereed Journal Issued by Lebanese French University - Erbil, Kurdistan, Iraq

Vol. (6), No (2), Spring 2021

ISSN 2518-6566 (Online) - ISSN 2518-6558 (Print)

\section{Hypsometric Curve of Khabour River Sub-basin}

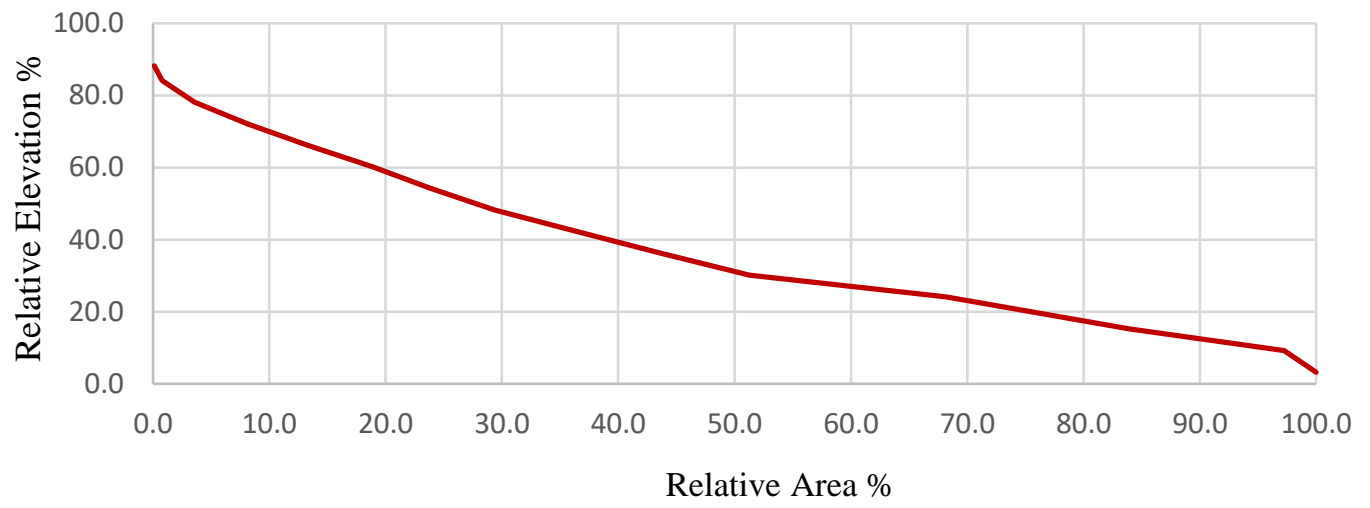

Hypsometric Curve of Hizel River Sub-basin

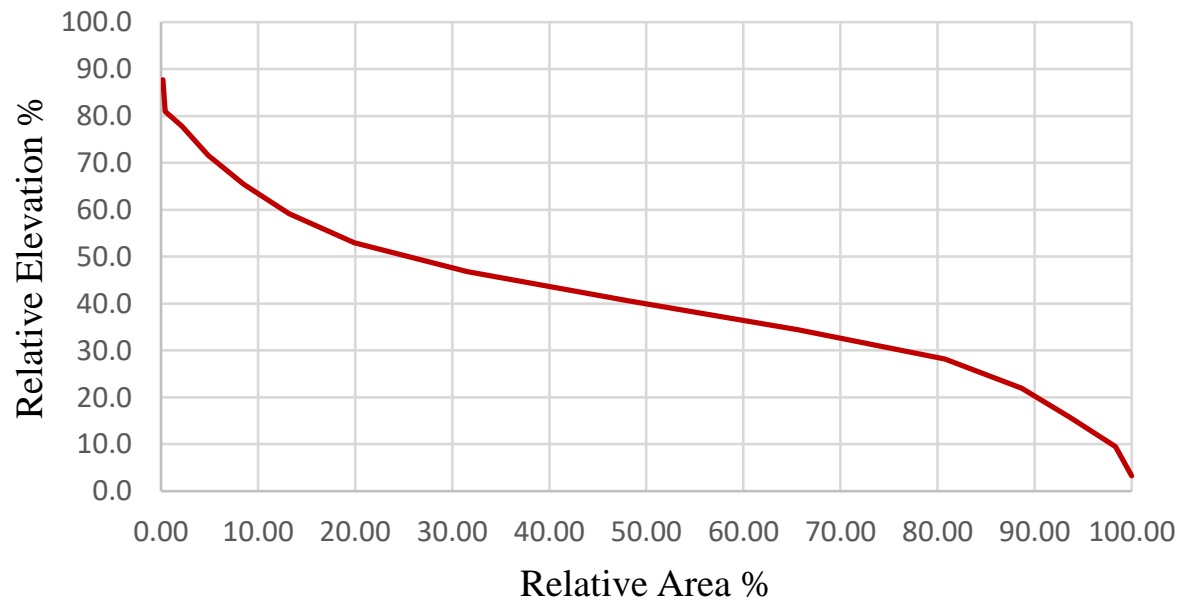

Figure (6) the heptometric curve of the study area and its sub-basins.

\section{conclusion}

The relief aspects play an important role in the development of basins, surface and subsurface water runoff, permeability, development of basin landforms, and characteristics of rocks erosion [45]. Landform relief increase, surface complexity, and 
severity of slope cause water drainage increases that resulted in an increase in runoff speed, lower rates of water leakage, deeper cannula and drainage, degradation, and sedimentary output[46]. Based on the data and results of the relief aspects of the Khabour River basin and sub-basins, it has been concluded that the study area basin is characterized by high relief numbers, complex mountain nature, and severe slopes. It is therefore a modern basin, which still has a great deal of time to go to its degradation. These numbers differ between their two sub-basins. The low-rate-of Relief ratio numbers of Hezel sub-basin indicate that it is more powerful and effective in transporting the product of erosion from sediment from Khabour sub-basin because there is a close correlation between the disassembled sediment in the area unit with the relief ratios so that the complex topography is associated with its small basin area based on [20]. Ruggedness number (Rn) which refers to relief structural complexity according to [45]. It is either in the main basin or its sub-basins reflecting erosive activity and that its basins are in the stage of development, as they are still in the youth stage. This trend is supported by the Geometric number (GN), whose low values indicate that the basin is still at the beginning of its geomorphologic phase, as well as the activity of erosion and sedimentary transport in the basin. Furthermore, slope indicators in the study area, whether related to the river channel or river basin, indicate the recent geomorphological age of the studied area and erosion activity. Topographic factors such as steep slope and ruggedness factors associated with the quality of rocks, especially limestone, which exacerbate the aquatic capacity of erosion and associated mass sediment transfers, form different geological forms in addition to guessing the quantity and quality of sediment transported, and increase the speed of water product.

\section{REFERENCES:}

[1] Strahler, A.N. (1952), Hypsometric (area-altitude) analysis of erosional topography. Geol. Soc. Am. Bull. 63, 1117-42.

[2]Sharma, H.S. (1981), Perspectives in geomorphology, Concept publishing company, New Delhi, pp.107-108.

[3] Abu Hasera, Yahya Mahmoud, 2013), Application of Geographical Information Systems in the Study of Morphometric Features of the Awja River Basin - Palestine, Unpublished Master Thesis, Department of Geography, College of Arts, Salmiya University - Gaza, p. 78. 


\section{QALAAI ZANISTSCIENTIFIC JOURNAL}

A Scientific Quarterly Refereed Journal Issued by Lebanese French University - Erbil, Kurdistan, Iraq

Vol. (6), No (2), Spring 2021

ISSN 2518-6566 (Online) - ISSN 2518-6558 (Print)

[4]Schumm, S.A. (1977), Drainage basin morphology, Benchmark Papers Geol. no. 41, Stroudsburg, Pa., Dowden, Hutchinson \& Ross.

[5]Ali, Sabah H. and Al-Ubide, Waleed Y. (2011), Spatial Analysis of Jabal Bekhier Elevation by Using GIS and Remote Sensing, J. Edu. \& Sci., Vol. 24, No. 4, p.p 87-100.

[6]Al Allawi, M.N.1980., "Structural study of Upper Cretaceous and Tertiary Succession in Jabel bekhair ,Dohuk area, N-Iraq", M.Sc. Thesis, University of Mosul.

[7]Abdulla, Hamed H. (2013) Rock Slop Analysis in Duhok Governorate /Bekhair Anticline by Using GIS Technique, Journal of Al-Nahrain University Vol.16 (4), pp.46-54.

[8]Abbas, Nahlah, Wasimi, Saleh and Al-Ansari, Nadhir, (2016), Assessment of Climate Change Impacts on Water Resources of Khabour in Kurdistan-Iraq, Using SWAT Model, Journal of Environmental Hydrology,Vo.24, p.p.1-19.

9]Al-Ansari, N., Adamo, N., Sissakian, V., Knutsson, S., and Laue, J. (2018), Water Resources of the Tigris River Catchment, Journal of Earth Sciences and Geotechnical Engineering, vol. 8, no. 3, pp. 21-42.

[10]Adamo, N., Al-Ansari, N., Sissakian, V., Sven Knutsson, S., and Laue, J. (2018), Climate Change: The Uncertain Future of Tigris River Tributaries' Basins, Journal of Earth Sciences and Geotechnical Engineering, vol. 8, no. 3, pp. 75-93.

[11] Husing, S., Zachariasse, W., Van Hinsbergen, D., Krijgsman, W., Inceoz, M., Harzhauser, M., Mandic, O. \& Kroh, A. (2012), Oligocene-Miocene basin evolution in SE Anatolia, Turkey: constraints on the closure of the eastern Tethys gateway, From :Van Hinsbergen, D., Edwards, M. A. \& Govers, R. (2009), Collision and Collapse at the Africa-Arabia-Eurasia Subduction Zone. The Geological Society, London, Special Publications, 311, 107-132

[12] Al-Omari, Farouk and Sadiq, Ali, (1977), Geology of Northern Iraq, Mosul University Press, Mosul, pp. 66-69.

[13] Karim, K. H. (2006), Analytical Comparison Study Between Khabour and Tanjero Formations Northern Iraq, Iraqi Jour. Earth Sci., Vol.6, No.2, pp.1-12.

[14] Al-Shamzini, Yusef Salih, (2002), Erosion in the Wadi Dawin Basin - Study in Applied Geomorphology, Unpublished Master Thesis, Salahuddin University - Erbil, College of Arts, Department of Geography, p. 11.

[15] Al-Kouran, Bidaa Mahmoud, (2004), Forms of foothills in Mount Akri - a study in applied geomorphology, unpublished master's thesis, Salahuddin University - Erbil, Faculty of Arts, Department of Geography, p. 34.

[16] Al-Hassani, Hekmat, (2000), Geomorphology of Mount Permam and its river basins and their applications, unpublished Master Thesis, University of Salah al-Din - Erbil, Faculty of Arts, Department of Geography, p. 36.

[17] Hamid, Jaafar Muhammad, (1974), A study of the relationship of rain to the surface water discharged and suspended load in the Duhok River basin, unpublished master thesis, University of Mosul, College of Science, Department of Forestry, p. 28. 


\section{QALAAI ZANISTSCIENTIFIC JOURNAL \\ A Scientific Quarterly Refereed Journal Issued by Lebanese French University - Erbil, Kurdistan, Iraq \\ Vol. (6), No (2), Spring 2021 \\ ISSN 2518-6566 (Online) - ISSN 2518-6558 (Print)}

[18] Samurai, Maha Qahtan, (2007), Basra River Feeding Basin - Study in Natural Geography, Unpublished Master Thesis, University of Baghdad, College of Arts, Department of Geography, p.

[19]Schumm, S.A. (1956), Evolution of Drainage Systems and Slopes in Badlands at Perth Amboy, New Jersey. Geol. Soc. Am. Bull.67.

[20] Kabite, G. and Gessesse, B. (2018) Hydro-geomorphological characterization of Dhidhessa River Basin, Ethiopia, International Soil and Water Conservation Research, 6, 175183.

[21]Strahler, A. N. (1957), Quantitative analysis of watershed geomorphology. Trans. Am. Geophys. Union 38, 913-20.

[22]Zende, A., (2016), Quantitative Evaluation of Morphometric Parameters of Sakli River Using Geospatial Techniques, National Conference on Water Resources \& Flood Management with special reference to Flood Modelling, SVNIT Surat, pp. 1-16.

23]Gottschalk, L. C. (1964), Reservoir sedimentation in handbook of applied hydrology, McGraw Hill Book Company, New York (Section 7-1).

[24]Singh, S. (1995), Quantitative analysis of watershed geomorphology using remote sensing techniques. Ann Arid Zone 34(4): 243-251.

[25]Melton, M.A. (1958), Geometric properties of mature drainage systems and their representation in an E4 phase space. J. Geol. 66, 25-54.

[26]Strahler, A. N. (1964), Quantitative geomorphology of drainage basins and channel networks. In: Chow V.T., (ed.) Handbook of applied hydrology, McGraw-Hill, New York; 439476.

[27]Abdulla, Hamed, H., (2011), Morphometric parameters study for the lower part of lesser zap using GIS technique, Earth Science Department, College of Science, University of Baghdad, Iraq, 7, (2), pp. 127-155.

[28]Melton, M. A., (1965), The geomorphic and paleoclimatic significance of alluvial deposits in Southern Arizona. Jo. Geol 73:1-38

[29]Wilford D., Sakals, M., Innes, J., Sidle, R. and Bergerud, W. (2004), Recognition of debris flow, debris flood and flood hazard through watershed morphometrics, Landslides,1:61-66.

[30] Abu Raya, Ahmed Mohamed, (2007), The area extending between Al-Qusayr and Mursa Um Ghaj, Geomorphology study, unpublished PhD thesis, Department of Geography and Geographic Information Systems, Faculty of Arts, Alexandria University, p. 60.

[31]Singh, S. \& Dubey, A. (1994), Geo-environmental planning of watersheds in India, Allahabad, India, Chugh Publications, 28: 69.

[32]Nir, Dove, (1957), The ratio of relative and absolute altitude of Mt. Camel, Geographical Review, 47, 564-569.

[33]Miller, V.C. (1953), A quantitative geomorphic study of drainage basin characteristics in the Clinch Mountain area, New York: Columbia Uni., Department of Geology, ONR, Geography Branch, Technical Report.3:30. 


\section{QALAAI ZANISTSCIENTIFIC JOURNAL \\ A Scientific Quarterly Refereed Journal Issued by Lebanese French University - Erbil, Kurdistan, Iraq \\ Vol. (6), No (2), Spring 2021 \\ ISSN 2518-6566 (Online) - ISSN 2518-6558 (Print)}

[34] Wentworth, C.K. (1930) A simplified method of determining the average slope of land surfaces. American Journal of Science, 21:184-194.

[35] Chorley, R.J. (1972), Spatial analysis in geomorphology. Mathuen and Co. Ltd., London. [36]Singh, P., Gupta, A., \& Singh, M. (2014), Hydrological inferences from watershed analysis for water resource management using remote sensing and GIS techniques, The Egyptian Journal of Remote Sensing and Space Sciences, 17, 111-121.

[37] Sreedevi, P.D., Subrahmanyam, K. \& Ahmed, S. (2004), The significance of morphometric analysis for obtaining ground water potentiall zones in a structurally controlled terrain. Environmental Geology, 47, 412-420.

[38]Sibomana, A., Bhat, G. and Havyarimana, H. and V. (2018), Morphometric analysis of Kagunuzi sub basin in Kibira national park northwestern part of Burundi using geospatial techniques, International Journal of Development Research, Vol. 08, Issue, 02, pp.1916519173.

[39]Sreedevi, P.D., Owais,S., Khan, H. \& Ahmed,S. (2009), Morphometric analysis of a watershed of South India using SRTM data and GIS. Journal of Geological Society of India, 73(4), 543-552.

[40] Hurtez, J.E., Sol, C., and Lucazeau, F. (1999) Effect of drainage area on

Hypsometry from an analysis of small-scale drainage basins in the Siwalik Hills (Central Nepal), Earth surface processes and landforms, 24, 799-808.

[41]Strahler, A.N. (1952) Hypsometric (area-altitude) analysis of erosional topography, Geological society of America bulletin, 63, 1117-1141.

[42] Ritter, D.F., Kochel, R.C. and Miller, J.R. (2002) Process geomorphology. McGraw Hill, Boston.

[43] Dikpal, R.L., Prasad, T. J. R. and Satish, K. (2017) Evaluation of morphometric parameters derived from Cartosat-1 DEM using remote sensing and GIS techniques for Budigere Amanikere watershed, Dakshina Pinakini Basin, Karnataka, India, Appl. Water Sci. (7), p.p.4399-4414. https://link.springer.com/content/pdf/10.1007/s13201-017-0585-6.pdf

[44] Ibrahim, Sawsan A.R. (2019) Morphometric Analysis of The Al-teeb River Basin, SE Iraq, Using Digital Elevation Models and GIS, Iraqi Bulletin of Geology and Mining Vol.15, No.1, p.p.59-69.

[45]Reddy, G. P., Maji, A. K. and Gajbhiye, K. S. (2004), Drainage morphometry and its influence on landform characteristics in a basaltic terrain, Central India - a remote sensing and GIS approach. Inter. J. of Applied Earth Observation and Geoinformation, 6, pp. 1-16.

[46] Salama, Hassan Ramadan (2013), The Origins of Geomorphology, Dar Al-Masirah, Amman, Jordan.

[47] Strahlar, R.N. (1975) Physical Geography, John Wiley \& Sons, United States of America. 


\section{QALAAI ZANISTSCIENTIFIC JOURNAL}

A Scientific Quarterly Refereed Journal Issued by Lebanese French University - Erbil, Kurdistan, Iraq

Vol. (6), No (2), Spring 2021

ISSN 2518-6566 (Online) - ISSN 2518-6558 (Print)

\section{يـوختــه:}

ئامازمكانى بهرزونزمى داتا لهبارهى خهسيهتهانى دامالينى رِووباريى وهك خهسيهته

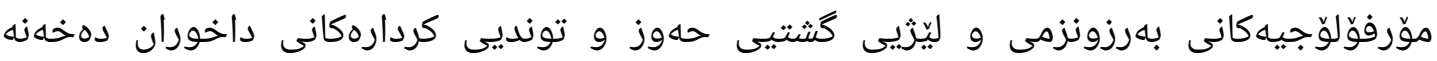

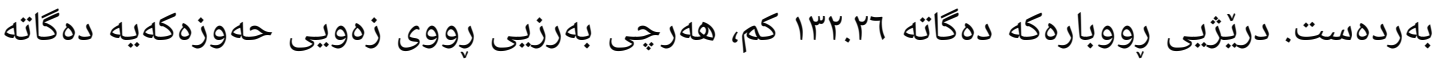

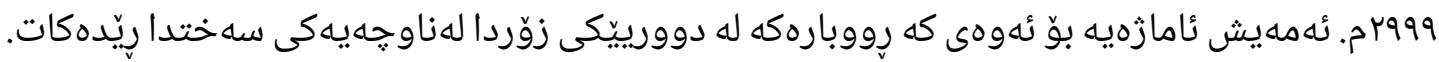

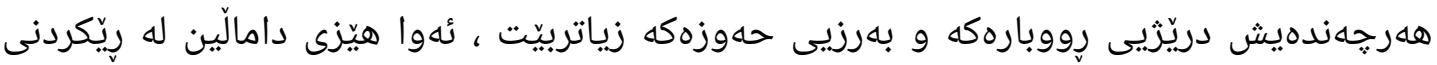

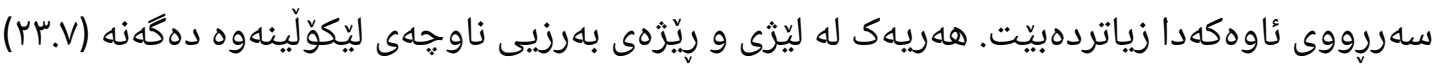

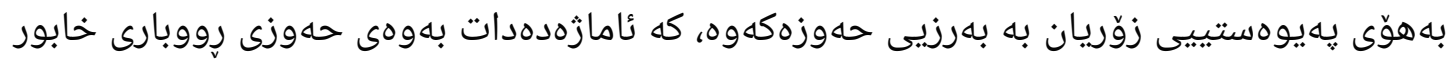

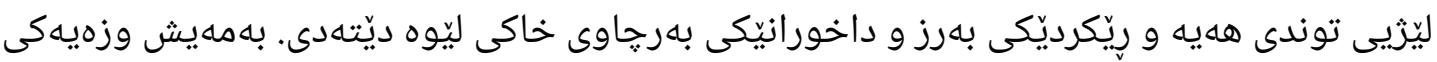

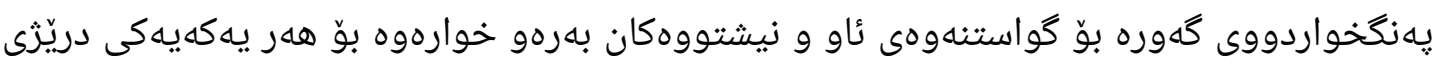

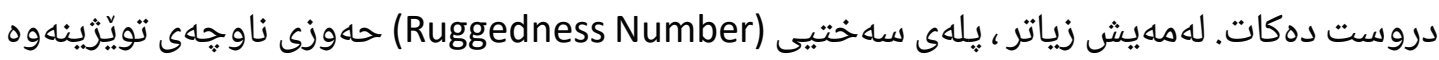
(V.Mr)

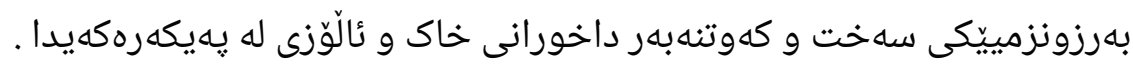

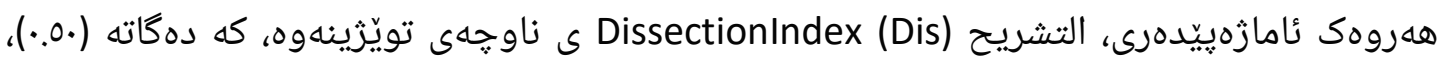

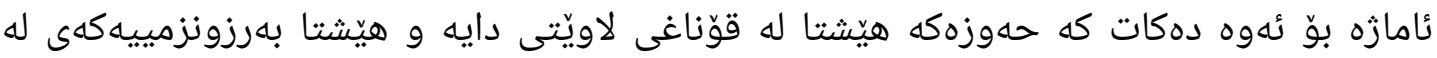

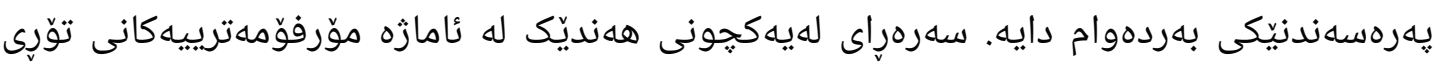

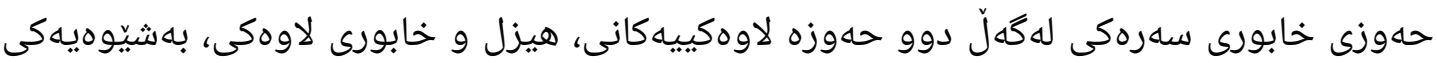

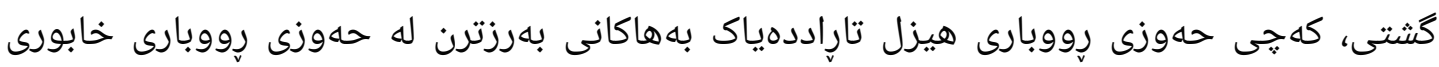

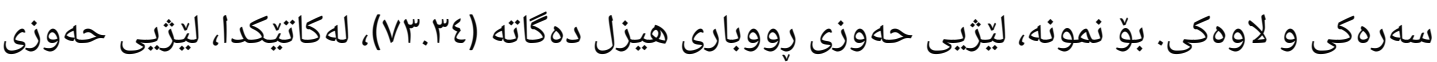

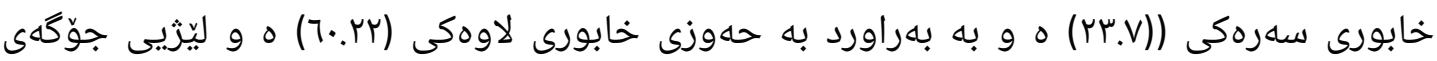

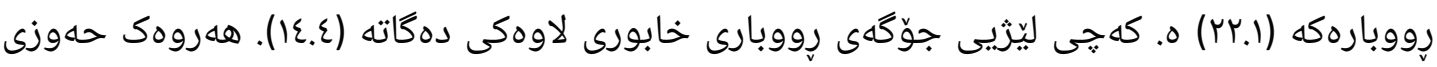

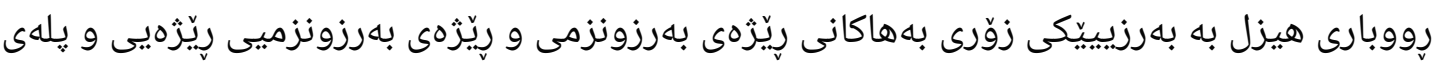

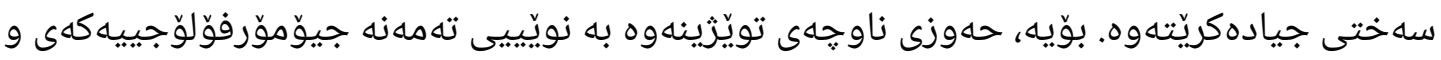

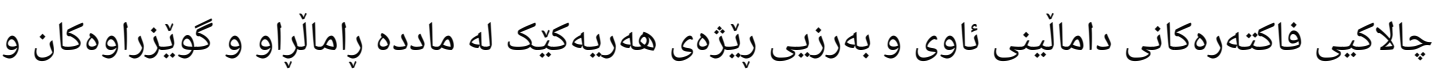

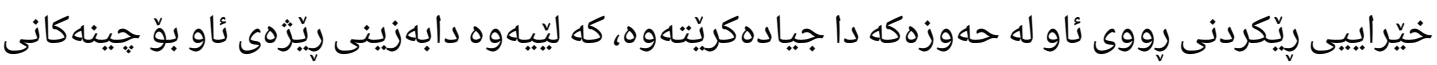




\section{QALAAI ZANISTSCIENTIFIC JOURNAL}

A Scientific Quarterly Refereed Journal Issued by Lebanese French University - Erbil, Kurdistan, Iraq

Vol. (6), No (2), Spring 2021

ISSN 2518-6566 (Online) - ISSN 2518-6558 (Print)

زيّر لِووى زهويى بههوّى سروشتى حهوزى شاخاويى نالِّوز و بههيّزيى لِّزَى و سهختى رِووهكهيهوه بكرههم ديّت. كليلى وشهكان: خهسيهته بهرزونزمييهكان، حهوزى رِووبار، دامالِينى رِووبارى، نيشتووهان

\section{التحديد المورفومثري للجوانب التضاريسية لحوض نهر الخابور}

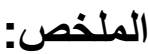

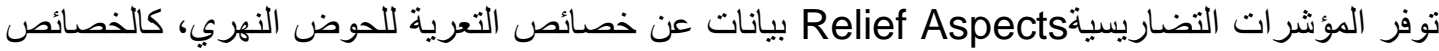

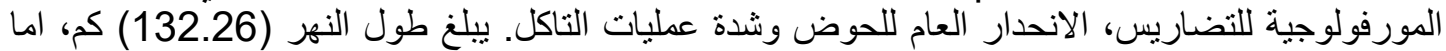

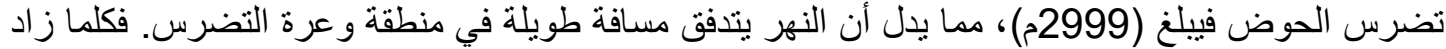

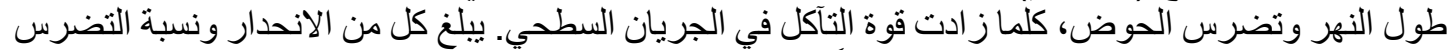

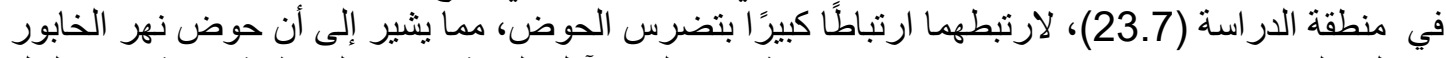

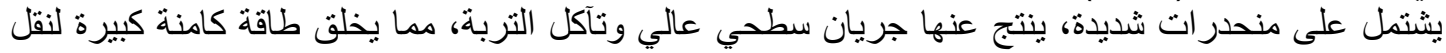

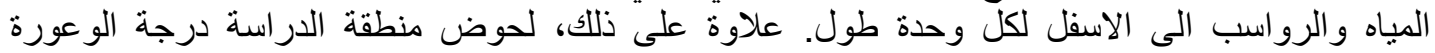
Ruggedness number التعرض لتآكل التربة وتعقيدها هيكليا.

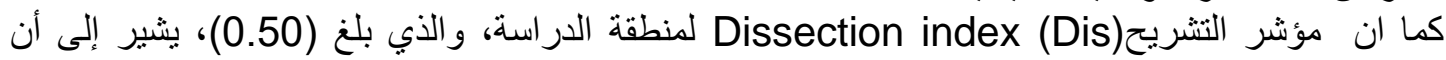

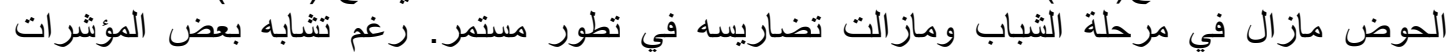

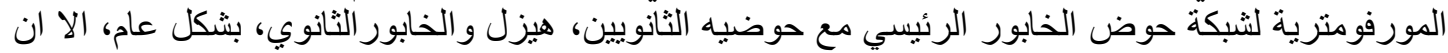

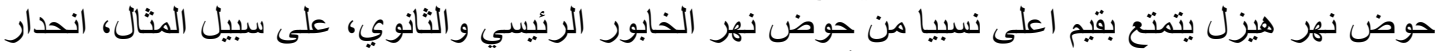

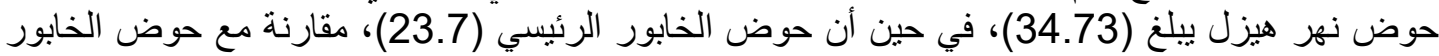

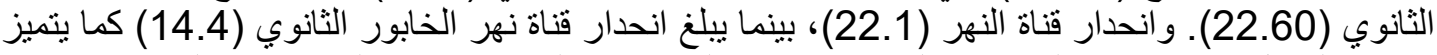

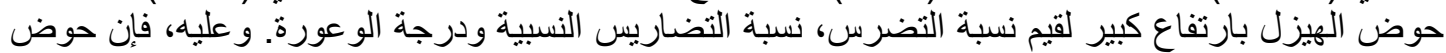

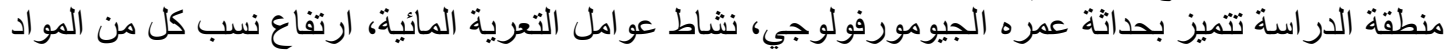

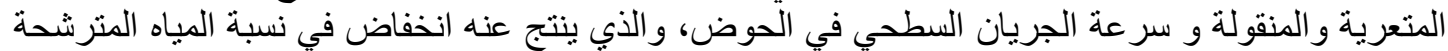
الى الطبقات التحت السطحية، بسبب طبيعة الحوض الجبلية المعقدة، شدة الانحدار وو لئه عورة سطحها. 